\title{
Erratum to: Effects of air temperature on the cyclic behavior of elastomeric seismic isolators
}

\author{
Donatello Cardone • Giuseppe Gesualdi • \\ Domenico Nigro
}

Published online: 8 March 2011

(C) Springer Science+Business Media B.V. 2011

\section{Erratum to: Bull Earthquake Eng DOI 10.1007/s10518-011-9244-8}

We found that one of the references in this paper is incorrect. More specifically,

George PM (2010) Effect of fault rupture characteristics on near-fault strong ground motions. Bull Seismol Soc Am 100(1):37-58

should be replaced by

Mavroeiidis GP and Papageorgiou AS (2010) Effect of fault rupture characteristics on near-fault strong ground motions. Bull Seismol Soc Am 100(1):37-58

In addition, in the sixth paragraph of section 3.2 Effects due to prolonged exposure to low temperatures, "George (2010)" should be replaced by "Mavroeidis and Papageorgiou (2010)".

The online version of the original article can be found under doi:10.1007/s10518-011-9244-8.

D. Cardone $(\varangle) \cdot$ G. Gesualdi · D. Nigro

University of Basilicata, Potenza, Italy

e-mail: donatello.cardone@unibas.it 